\title{
Desulfonatronovibrio hydrogenovorans gen. nov., sp. nov., an Alkaliphilic, Sulfate-Reducing Bacterium
}

\author{
T. N. ZHILINA, ${ }^{1}$ G. A. ZAVARZIN, ${ }^{1}$ F. A. RAINEY, ${ }^{2 *}$ E. N. PIKUTA, ${ }^{1}$ G. A. OSIPOV ${ }^{3}$ \\ AND N. A. KOSTRIKINA ${ }^{1}$ \\ Institute of Microbiology, Russian Academy of Sciences, 117811 Moscow, ${ }^{1}$ and State Institute of Biological Equipment \\ Manufacturing, Moscow, ${ }^{3}$ Russia, and Deutsche Sammlung von Mikroorganismen und Zellkulturen GmbH, \\ D-38124 Braunschweig, Germany ${ }^{2}$
}

\begin{abstract}
A new alkaliphilic, sulfate-reducing bacterium, strain $Z-7935^{T}(T=$ type strain), was isolated from a soda-depositing lake, Lake Magadi in Kenya. This organism is a motile vibrio which utilizes only hydrogen and formate as electron donors and sulfate, sulfite, and thiosulfate, but not sulfur, as electron acceptors. Thiosulfate is dismutated. Strain $Z-7935^{\mathrm{T}}$ is an obligately sodium-dependent alkaliphile which grows in sodium carbonate medium and does not grow at $\mathrm{pH} 7$; the maximum $\mathrm{pH}$ for growth is more than $\mathrm{pH} 10$, and the optimum pH is 9.5 to 9.7. The optimum $\mathrm{NaCl}$ concentration for growth is $3 \%$ (wt/vol). The optimum temperature for growth is $37^{\circ} \mathrm{C}$. The $\mathrm{G}+\mathrm{C}$ content of the DNA is $48.6 \mathrm{~mol} \%$. $16 \mathrm{~S}$ ribosomal DNA sequence analysis revealed that strain $Z-7935^{\mathrm{T}}$ represents a new lineage with genus status in the delta subclass of the Proteobacteria. The name Desulfonatronovibrio hydrogenovorans gen. nov., sp. nov. is proposed for this organism; the type strain of $D$. hydrogenovorans is strain Z-7935 (= DSM 9292).
\end{abstract}

The development of alkalinity is often ascribed to sulfatereducing bacteria, as suggested by Abd-el-Malek and Rizk for the Wadi-el-Natrun (1). Sulfate-reducing bacteria are thought to be responsible for the disappearance of sulfate in Lake Magadi. Direct evidence of sulfate reduction is found in the black muds interbedded with trona $\left(\mathrm{Na}_{2} \mathrm{CO}_{3} \cdot \mathrm{NaHCO}_{3}\right.$. $2 \mathrm{H}_{2} \mathrm{O}$ ), which indicate that $\mathrm{H}_{2} \mathrm{~S}$ was formed and sulfate was depleted in the groundwater and that subsequent binding of sulfide by iron occurred in trachitic lava rocks in Lake Magadi (2). However, as pointed out by Tindall (17), this theory has not been supported by the successful isolation of alkaliphilic sulfate reducers which can grow at $\mathrm{pH}$ values greater than 9 from soda lakes, in which the $\mathrm{pH}$ is often greater than 10 . Nevertheless, it has been shown for a group of Central Asian soda lakes with $\mathrm{pH}$ values greater than 9 that in these alkaliphilic environments, in which the salinity is as high as $15 \%$, sulfidogenesis constitutes a dominant hydrogen sink, competing with acetogenesis but not with methanogenesis, which occurs via the methylotrophic pathway with the utilization of methanol and/or methylamines (26). Thus, the search for and isolation of alkaliphilic, sulfate-reducing bacteria is important for our understanding of (i) the bacterial diversity which employs bioenergetics that are currently unknown or considered impossible, (ii) the role of these bacteria in community metabolism as the main electron sink for hydrogen-producing primary anaerobes, and (iii) the geochemical processes that are influenced by producers of extreme alkalinity in such environments. The processes for which causative agent(s) have yet to be isolated remain unelucidated from a microbiological point of view.

Isolation of alkaliphilic, hydrogen-consuming, sulfate-reducing bacteria from the alkaliphilic anaerobic community in Lake Magadi was first reported in 1994 (27). Here, we describe the isolation from Lake Magadi of an alkaliphilic, sulfate-reducing bacterium which grows in an extremely alkaline environment. The phylogenetic affiliation of this organism with representatives of the sulfate-reducing bacteria is described.

* Corresponding author. Present address: Department of Microbiology, Louisiana State University, Baton Rouge, LA 70803-1715.

\section{MATERIALS AND METHODS}

Sampling. A sample was collected from sediments of an alkaline lake, Lake Magadi (East African Rift, Kenya). The sample was taken during the dry season of 1991 from a trench dug into the trona; it was assumed that the liquor at the sample site came from a depth of 8 to $10 \mathrm{ft}$ under the surface of the trona and was enriched with $\mathrm{NaCl}$. Subsamples of the mud were taken anaerobically, and these subsamples were transported to Moscow at the ambient temperature; in the laboratory they were stored at $4^{\circ} \mathrm{C}$.

Media and growth conditions. Selective alkaline medium II (27) containing (per liter) $15 \mathrm{~g}$ of $\mathrm{NaHCO}_{3}, 10 \mathrm{~g}$ of $\mathrm{Na}_{2} \mathrm{CO}_{3}, 10 \mathrm{~g}$ of $\mathrm{NaCl}, 1 \mathrm{~g}$ of $\mathrm{NH}_{4} \mathrm{Cl}, 0.2 \mathrm{~g}$ of $\mathrm{KCl}, 0.2 \mathrm{~g}$ of $\mathrm{K}_{2} \mathrm{HPO}_{4}, 3 \mathrm{~g}$ of $\mathrm{Na}_{2} \mathrm{SO}_{4}, 0.5 \mathrm{~g}$ of $\mathrm{Na}_{2} \mathrm{~S} \cdot 9 \mathrm{H}_{2} \mathrm{O}, 10 \mathrm{ml}$ of a vitamin solution (24), $1 \mathrm{ml}$ of a trace element solution (21), $0.5 \mathrm{~g}$ of yeast extract, and $\mathrm{H}_{2}$ or formate as the substrate was used for enrichment and isolation. A pure culture was maintained in an optimized medium formulated after the study of the physiology of the new isolate was completed and was cultivated under strictly anaerobic conditions in rubber membrane-sealed glass vessels with $\mathrm{H}_{2}$ in the gas phase. The optimized medium contained (per liter) $3.5 \mathrm{~g}$ of $\mathrm{Na}_{2} \mathrm{CO}_{3}, 24 \mathrm{~g}$ of $\mathrm{NaHCO}_{3}$ (added after cooling), $20 \mathrm{~g}$ of NaCl, $5 \mathrm{~g}$ of $\mathrm{Na}_{2} \mathrm{SO}_{4}, 0.2 \mathrm{~g}$ of $\mathrm{K}_{2} \mathrm{HPO}_{4}$, $0.1 \mathrm{~g}$ of $\mathrm{MgCl}_{2} \cdot 7 \mathrm{H}_{2} \mathrm{O}, 0.5 \mathrm{~g}$ of $\mathrm{NH}_{4} \mathrm{Cl}, 0.2 \mathrm{~g}$ of $\mathrm{KCl}, 0.12 \mathrm{~g}$ of sodium acetate or $0.5 \mathrm{~g}$ of yeast extract, $10 \mathrm{ml}$ of a vitamin solution (24), $1 \mathrm{ml}$ of a trace element solution (21), and $0.5 \mathrm{~g}$ of $\mathrm{Na}_{2} \mathrm{~S} \cdot 9 \mathrm{H}_{2} \mathrm{O}$ or thioglycolate (final pH 9.5). Cultures were incubated at $37^{\circ} \mathrm{C}$. The substrates (electron donors) used were $\mathrm{H}_{2}$ in the gas phase and sodium formate ( $5 \mathrm{~g} /$ liter, with $\mathrm{N}_{2}$ in gas phase). Electron acceptors were added at the following concentrations: $\mathrm{Na}_{2} \mathrm{SO}_{4}{ }^{2-}, 30 \mathrm{mM} ; \mathrm{Na}_{2} \mathrm{SO}_{3}{ }^{2-}$, 5 $\mathrm{mM} ; \mathrm{Na}_{2} \mathrm{~S}_{2} \mathrm{O}_{3}{ }^{2-}, 10 \mathrm{mM} ; \mathrm{NaNO}_{3}{ }^{-}, 10 \mathrm{mM}$; sodium fumarate, $10 \mathrm{mM} ; \mathrm{S}^{\mathrm{o}^{\prime}}, 2$ $\mathrm{g} /$ liter; and dimethyl sulfoxide, $2 \mathrm{ml} / \mathrm{liter}$. Twenty-milliliter portions of the medium were distributed into $100-\mathrm{ml}$ rubber-stoppered screw-cap flasks by using a standard strictly anaerobic technique. In the case of roll tube cultivation, $2 \%$ (wt/vol) agar (Difco Laboratories, Detroit, Mich.) was added to 4-ml portions of carbonate-free medium. The carbonate solution was injected into Hungate tubes after sterilization. $\mathrm{NaCl}$ requirements were studied with optimized medium in which the $\mathrm{Na}_{2} \mathrm{CO}_{3}$ and $\mathrm{NaHCO}_{3}$ were replaced by $5 \mathrm{~g} \mathrm{of}_{2} \mathrm{CO}_{3}$ per liter and the $\mathrm{Na}_{2} \mathrm{~S}$ was replaced by $\mathrm{K}_{2} \mathrm{~S}$. Growth, detected as visible turbidity, was measured by determining the optical density at $600 \mathrm{~nm}$ in Hungate tubes with a spectrophotometer (Spekol, Jena, Germany) equipped with a type ER tube adapter. Microscopic counts were also used to determine growth. The $\mathrm{pH}$ limits for growth and sulfidogenesis were determined in the carbonate medium containing $10 \mathrm{~g}$ of $\mathrm{Na}_{2} \mathrm{CO}_{3}$ per liter and $15 \mathrm{~g}$ of $\mathrm{NaHCO}_{3}$ per liter; the $\mathrm{pH}$ was adjusted to the appropriate value by adding $6 \mathrm{~N} \mathrm{NaOH}$ or $6 \mathrm{~N} \mathrm{HCl}$ to an anaerobic fiask with a built-in $\mathrm{pH}$ electrode under a stream of $\mathrm{N}_{2}$. After the dispensed medium had been autoclaved and the $\mathrm{pH}$ had been verified, the flasks were inoculated with a $1 \%(\mathrm{vol} / \mathrm{vol})$ inoculum and incubated for 9 days at $37^{\circ} \mathrm{C}$. The growth response was measured by determining sulfide formation and turbidity. Sulfidogenesis at different $\mathrm{pH}$ values was measured by monitoring $\mathrm{H}_{2} \mathrm{~S}$ formation from radiolabelled sulfate at $37^{\circ} \mathrm{C}$ during incubation for $24 \mathrm{~h}(5,20)$. All of the chemicals used in this study were obtained from Russian suppliers.

Analytical procedures. The presence of desulfoviridin was checked fluorometrically by using a spectrofluorimeter (Hitachi, Tokyo, Japan) (10). $\mathrm{H}_{2} \mathrm{~S}$ was quantified by the methylene blue reaction and colorimetric detection (18). Sulfate consumption (or formation of sulfate from $\mathrm{Na}_{2} \mathrm{~S}_{2} \mathrm{O}_{3}$ ) was measured by a 
nephelometric reaction with $\mathrm{BaCl}_{2}$ (4). Hydrogen consumption was monitored by measuring pressure and/or by gas chromatography with a type $5 \mathrm{~A}$ molecular sieve column. Lipids were extracted from cell biomass that was dried in a stream of helium and then under a vacuum. To $30 \mathrm{mg}$ of dry biomass, $200 \mu \mathrm{l}$ of a $5.4 \mathrm{~N}$ solution of anhydrous $\mathrm{HCl}$ in methanol was added, and the mixture was heated at $70^{\circ} \mathrm{C}$ for $2 \mathrm{~h}$. The methyl esters of fatty acids and aldehyde derivatives obtained were extracted twice with $100 \mu \mathrm{l}$ of hexane. The extract was dried and silylated in $20 \mu \mathrm{l}$ of $N, O$-bis(trimethylsilyl)trifluoroacetamide for $15 \mathrm{~min}$ at $65^{\circ} \mathrm{C}$. A $1-\mu$ portion of the reaction mixture was analyzed with a model HP-5985B gas chromatography-mass spectrometry system (Hewlett-Packard, Palo Alto, Calif.) equipped with a capillary column ( 25 by $0.25 \mathrm{~mm}$ ) consisting of fused quartz containing an Ultra-1 nonpolar methylsilicone phase. The temperature profile included a $2-\mathrm{min}$ isotherm at $150^{\circ} \mathrm{C}$ and subsequent programmed temperature increases (the temperature was increased at a rate of $5^{\circ} \mathrm{C} / \mathrm{min}$ to $250^{\circ} \mathrm{C}$ and then at a rate of $10^{\circ} \mathrm{C} / \mathrm{min}$ to $300^{\circ} \mathrm{C}$ ). Data processing was carried out with an HP-1000 computer by using the standard programs of the gas chromatography-mass spectrometry system (Hewlett-Packard).

Microscopy. The morphology of cultures was observed with an anoptral Zetopan microscope (Reicherdt, Vienna, Austria). Negative staining of whole cells by phosphotungstic acid and fixation for preparation of thin sections were carried out as described previously (28). Microscopy was performed with a model JEM$100 \mathrm{C}$ electron microscope (JEOL, Tokyo, Japan).

G+C content. The guanine-plus-cytosine $(G+C)$ content of the genomic DNA was determined by a thermal denaturation method (9). Escherichia coli K-12 DNA was used as the standard.

$16 S$ rDNA sequence determination and data analysis. Genomic DNA was extracted and the gene coding for 16S rRNA (16S rDNA) was amplified as described previously (12). Purified PCR products were directly sequenced by using a Taq DyeDeoxy terminator cycle sequencing kit (Applied Biosystems, Foster City, Calif.). Sequence reaction mixtures were electrophoresed with an Applied Biosystems model 373A DNA sequencer. The 16S rDNA sequence of strain Z-7935 ${ }^{\mathrm{T}}$ ( $\mathrm{T}=$ type strain) was manually aligned with sequences of representatives of the delta subclass of the Proteobacteria. Pairwise evolutionary distances were computed by using the correction of Jukes and Cantor (6). The neighbor-joining method was used to reconstruct a phylogenetic tree from the distance matrices (14)

Nucleotide sequence accession numbers. The $16 \mathrm{~S}$ rDNA sequences determined in this study are available from EMBL under accession numbers X99234 to X99237.

\section{RESULTS}

Enrichment and isolation. The sediment sample used in this study had an oily black appearance, and a white mineral film formed on the surface. The purple bacteria usually found in the lagoons of Lake Magadi were absent at the sampling site. At the moment of sampling, the $\mathrm{pH}$ of the water was 10.2 and the temperature was $50^{\circ} \mathrm{C}$. Samples of the sediment from Lake Magadi were incubated in 100-ml screw-cap bottles containing selective alkaline medium II ( $\mathrm{pH} 9.7)$ with $\mathrm{H}_{2}$ as the substrate; after several weeks of incubation, dominant vibrioid bacteria were observed. A pure culture was isolated by the serial dilution method in liquid selective alkaline medium II containing $0.5 \mathrm{~g}$ of yeast extract per liter and $\mathrm{H}_{2}$ as the substrates. Colonies of the sulfate reducer were obtained in roll tubes with sodium formate as the substrate. The colonies were yellowish, translucent, lens shaped, and less than $0.2 \mathrm{~mm}$ in diameter. The purity of the culture was indicated by the absence of growth on glucose-peptone sulfate-free medium containing excessive quantities of yeast extract. The absence of growth in media containing various substrates utilized by sulfate-reducing bacteria provided additional proof of purity. Several single colonies were isolated. One of these colonies, designated strain $\mathrm{Z}-7935^{\mathrm{T}}$, was chosen for further characterization.

Morphology. Strain Z-7935 ${ }^{\mathrm{T}}$ is a highly motile vibrio with a polar flagellum and filamentous appendages (Fig. 1). Motility was observed in young cultures but drastically diminished during 1 year of subcultivation. At $\mathrm{pH} 10$ short spirilla were observed. The cells, which occurred singly or in pairs, were 0.5 $\mu \mathrm{m}$ in diameter and 1.5 to $2 \mu \mathrm{m}$ long. Multiplication was by binary fission with the formation of two sister cells (Fig. 1b). The cell wall had a typical gram-negative structure in ultrathin sections, and the periplasmic space was well-developed (Fig. 2). Spores were never observed.

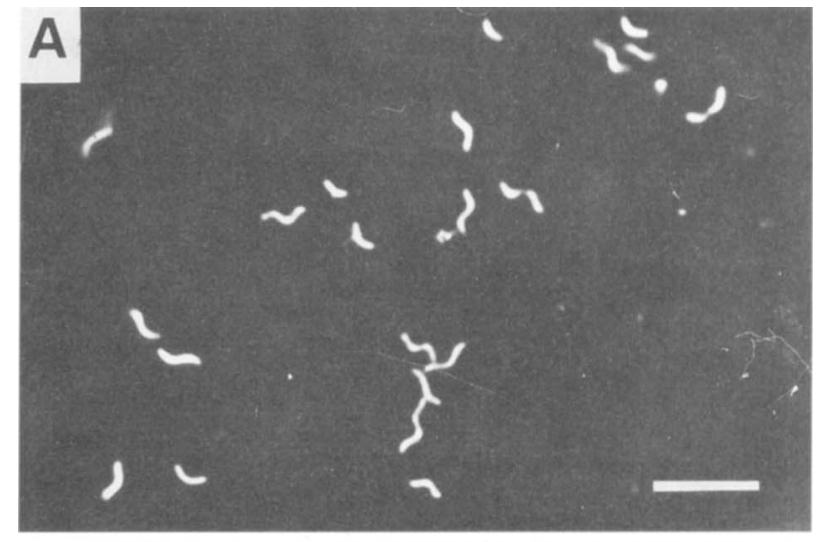

B
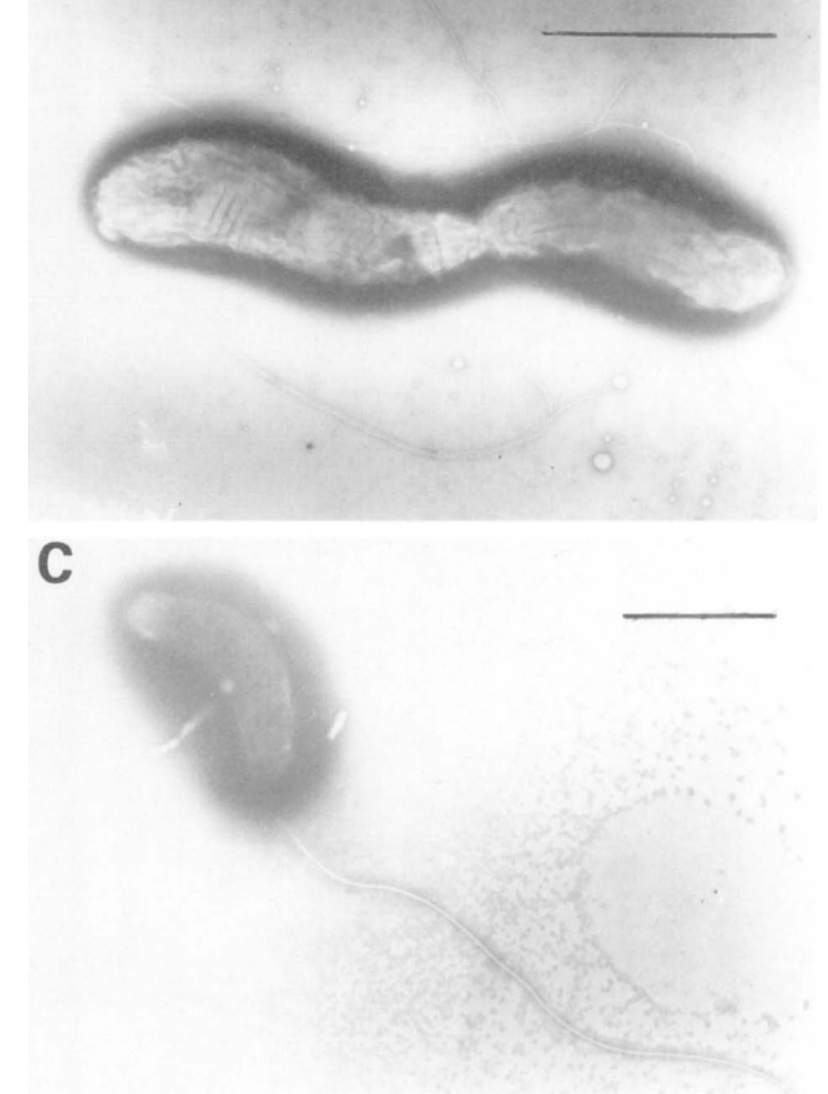

FIG. 1. Morphology of strain Z-7935 ${ }^{\mathrm{T}}$. (A) Cells as viewed with the anoptral microscope. Bar $=10 \mu \mathrm{m}$. (B) Negatively stained dividing cells. Note the surface and appendages. Bar $=1 \mu \mathrm{m}$. (C) Negatively stained cell with monopolar flagellum. Bar $=1 \mu \mathrm{m}$.

Metabolic properties. Strain Z- $7935^{\mathrm{T}}$ is very restricted with respect to the range of electron donors utilized. A total of 28 substrates were tested as electron donors, and only $\mathrm{H}_{2}$ and formate were utilized. No growth occurred on the following compounds (each at a concentration of $5 \mathrm{~g} /$ liter): acetate, propionate, butyrate, pyruvate, lactate, malate, fumarate, succinate, methanol, ethanol, glycerol, glycine, cysteine, cystine, serine, alanine, glutamate, aspartate, Casamino Acids, yeast extract, choline, betaine, glucose, fructose, rhamnose, and mannose. Sulfate, sulfite, and thosulfate were utilized as elec- 


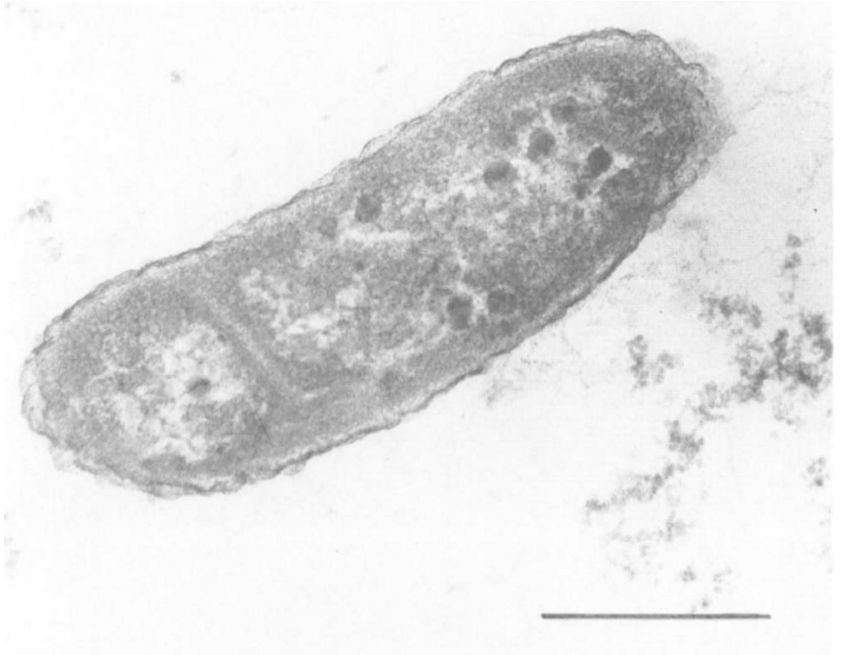

FIG. 2. Ultrastructure of strain Z-7935 ${ }^{\mathrm{T}}$. Bar $=0.5 \mu \mathrm{m}$.

tron acceptors. Formation of sulfide was observed in the presence of dimethyl sulfoxide; however, there was no growth in subcultures. Elemental sulfur inhibited growth. Fumarate and nitrate did not support growth. Strain Z-7935 ${ }^{\mathrm{T}}$ was strictly anaerobic, and its growth was inhibited by air. Thiosulfate was decomposed; equimolar quantities of sulfate and $\mathrm{H}_{2} \mathrm{~S}$ were formed from $10 \mathrm{mmol}$ of thiosulfate, indicating that the organism had the ability to dismutate.

Growth conditions. Like most hydrogen-consuming, sulfatereducing bacteria, strain $\mathrm{Z}-7935^{\mathrm{T}}$ needs organic compounds for anabolic reactions, and so its type of nutrition can be described as lithoheterotrophic. Growth dependence on yeast extract was observed (Fig. 3). However, yeast extract could be partially replaced by vitamins and acetate as a carbon source. A sodium acetate concentration of $0.16 \mathrm{~g} /$ liter was sufficient for optimal growth. The limits for growth and sulfidogenesis were determined with various $\mathrm{pH}$ values and salt contents. In growth experiments sulfidogenesis occurred without a lag phase at $\mathrm{pH}$ values between 9.5 and 9.7; this range of $\mathrm{pH}$ values was optimal, based on the rate of sulfide formation, and growth occurred at $\mathrm{pH} 8.0$ to 10.2 . In short-time experiments with radioactive sulfate, sulfidogenesis increased linearly to a maximal value at $\mathrm{pH} 9.5$ and rapidly decreased to one-tenth the maximal value at $\mathrm{pH} 10$. The $\mathrm{pH}$ of the medium did not change

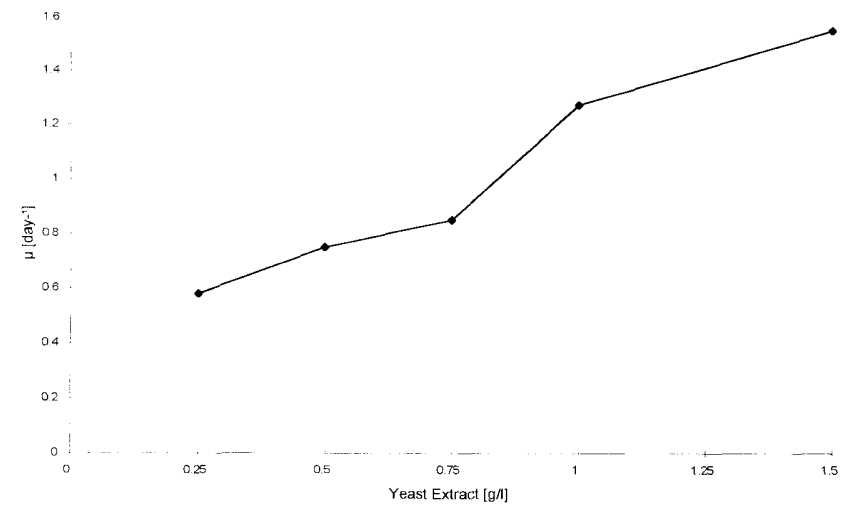

FIG. 3. Effect of yeast extract concentration on the specific growth rate $(\mu)$ of strain Z-7935 .
TABLE 1. Fatty acids in the cells of strain $\mathrm{Z}-7935^{\mathrm{T}}$ and Desulfohalobium retbaense $\mathrm{HR}_{100}$

\begin{tabular}{|c|c|c|}
\hline \multirow[b]{2}{*}{ Fatty acid } & \multicolumn{2}{|c|}{$\%$ of total fatty acids in: } \\
\hline & Strain Z-7935 & $\begin{array}{l}\text { Desulfohalobium } \\
\text { retbaense } \mathrm{HR}_{100}{ }^{a}\end{array}$ \\
\hline $\mathrm{C}_{13: 0}$ & 0 & 0.11 \\
\hline iso- $\mathrm{C}_{14 \cdot 0}$ & 1.9 & $1.68 \pm 0.1$ \\
\hline $\mathrm{C}_{14: 0}$ & 5.6 & 0.95 \\
\hline iso- $\mathrm{C}_{15: 0}$ & 3.7 & $15.28 \pm 2.3$ \\
\hline anteiso- $\mathrm{C}_{15 \cdot 0}$ & 3.9 & $3.6 \pm 0.3$ \\
\hline$C_{15.1} \omega-6$ & 0 & 0.23 \\
\hline $\mathrm{C}_{15: 0}$ & 2.6 & $3.93 \pm 0.4$ \\
\hline iso- $\mathrm{C}_{1600}$ & 4.4 & $5.34 \pm 0.5$ \\
\hline$C_{16: 1} \omega-9$ & 0 & 0.58 \\
\hline$C_{16: 1} \omega-7$ & 2.7 & $4.10 \pm 0.7$ \\
\hline$C_{160}$ & 32.8 & $13.33 \pm 2.8$ \\
\hline iso- $C_{17: 1} \omega-7 \mathrm{c}$ & 0 & $3.88 \pm 0.1$ \\
\hline iso- $C_{17: 0}$ & 1.1 & $1.9 \pm 0.4$ \\
\hline anteiso- $\mathrm{C}_{17: 0}$ & 2.1 & $2.24 \pm 1.1$ \\
\hline $\mathrm{C}_{17 .} \omega-8$ & 0 & $8.05 \pm 1.5$ \\
\hline$C_{17: 1} \omega-6$ & 0 & $0.71 \pm 0.6$ \\
\hline $\mathrm{C}_{17: 0}$ & 5.9 & $3.33 \pm 0.8$ \\
\hline Branched $C_{18,1} \omega-6$ & 0 & 0.36 \\
\hline$C_{18: 1} \omega-9$ & 3.4 & 0 \\
\hline$C_{1} \cdot \omega-7 c$ & 0 & $6.53 \pm 2.2$ \\
\hline $\mathrm{C}_{18: 1} \omega-5 \mathrm{c}$ & 0 & 0.23 \\
\hline$C_{18: 1} \omega-11$ & 5.9 & $3.86 \pm 1.4$ \\
\hline $\mathrm{C}_{18: 0}$ & 18.2 & $15.97 \pm 5.2$ \\
\hline cyclo $\mathrm{C}_{19: 0}$ & 0 & 0.43 \\
\hline $\mathrm{C}_{19: 1}$ & 1.0 & 0 \\
\hline $\mathrm{C}_{20: 0}$ & 1.6 & 0 \\
\hline
\end{tabular}

${ }^{a}$ Data from reference 8 .

during growth. At $\mathrm{pH}$ values higher than 10 there was a decrease in the rate of sulfidogenesis, while at $\mathrm{pH} 11.5$ to 12 formation of $\mathrm{H}_{2} \mathrm{~S}$ did not occur. Strain $\mathrm{Z}-7935^{\mathrm{T}}$ is an obligate alkaliphile which does not grow at $\mathrm{pH} 7$; carbonate ions are required for growth. When $\mathrm{Na}_{2} \mathrm{CO}_{3}-\mathrm{NaHCO}_{3}$ was replaced by $\mathrm{NaCl}$ and the $\mathrm{pH}$ values were maintained with $50 \mathrm{mM}$ serine buffer $\left(\mathrm{pK}_{\mathrm{a}}, 9.4\right)$, no growth occurred. Dependence on sodium was studied in media containing $5 \mathrm{~g}$ of $\mathrm{K}_{2} \mathrm{CO}_{3}$ per liter and increasing concentrations of $\mathrm{NaCl}$. There was no growth or sulfidogenesis without sodium ions. Maximal sulfidogenesis was observed in the presence of $3 \%$ (wt/vol) $\mathrm{NaCl}$, and at higher $\mathrm{NaCl}$ concentrations sulfidogenesis decreased. Strain $\mathrm{Z}-7935^{\mathrm{T}}$ is a weak halophile that is obligately dependent on sodium ions. Dependence on chloride ions was not detected. Strain $\mathrm{Z}-7935^{\mathrm{T}}$ is a mesophile. The optimal temperature for growth was $37^{\circ} \mathrm{C}$, while at $40^{\circ} \mathrm{C}$ growth stopped after a fast start. At 45 and $15^{\circ} \mathrm{C}$ there was no growth, and at 22 or $26^{\circ} \mathrm{C}$ growth began after a lag phase. Desulfoviridin, a pigment common to Desulfovibrio species, was not found in strain Z-7935 ${ }^{\mathrm{T}}$.

Lipid analysis. The fatty acid distribution in the cells of strain $\mathrm{Z}-7935^{\mathrm{T}}$ is shown in Table 1 . Saturated fatty acids accounted for $66.7 \%$ of the total fatty acids, with $C_{16: 0}$ and $C_{18: 0}$ acids predominating. Branched saturated fatty acids accounted for only $11 \%$ of the total fatty acids. The following monounsaturated fatty acids, which accounted for $12 \%$ of the total fatty acids, were also present: $C_{16: 1}, C_{18: 1} \omega-9, C_{18: 1} \omega-11$, and $C_{19: 1}$ fatty acids. The absence in strain $\mathrm{Z}-7935^{\mathrm{T}}$ of isoheptadecenoic acid (iso $\left.\mathrm{C}_{17: 1}\right)$ and the presence of cis-vaccenic acid $\left(\mathrm{C}_{18: 1}\right.$ $\omega$-11) are notable.

DNA base composition. The $\mathrm{G}+\mathrm{C}$ content of the DNA of strain $\mathrm{Z}-7935^{\mathrm{T}}$ is $48.6 \mathrm{~mol} \%$. 


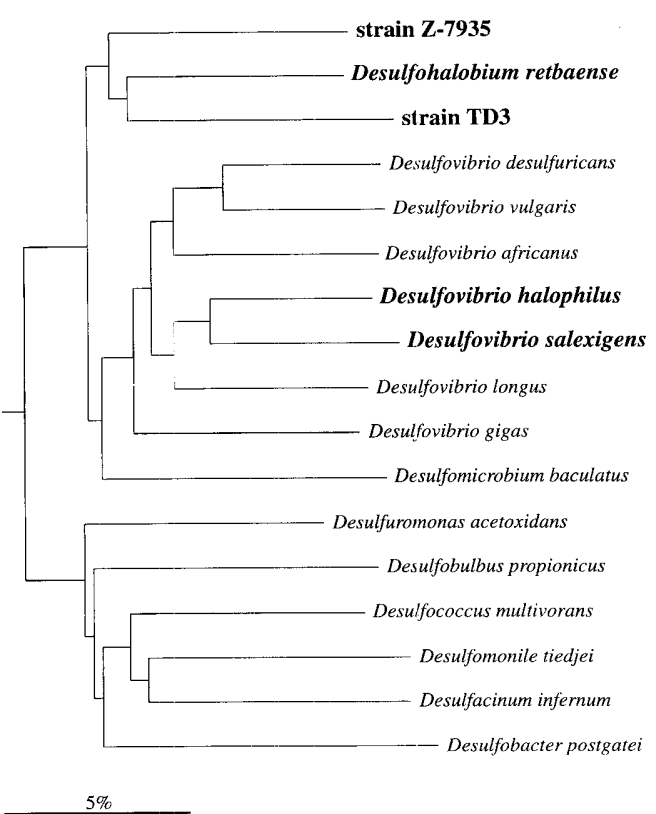

FIG. 4. Phylogenetic dendrogram showing the position of alkaliphilic, sulfate-reducing bacterial strain $\mathrm{Z}-7935^{\mathrm{T}}$ within the radiation of sulfate-reducing bacteria belonging to the delta subclass of the Proteobacteria. The position of the root was determined by including Escherichia coli as an outgroup organism. Scale bar $=5$ inferred substitutions per 100 nucleotides.

Phylogenetic analysis. An almost complete $16 \mathrm{~S}$ rDNA sequence comprising 1,503 nucleotides was determined for strain Z-7935 ${ }^{\mathbf{T}}$. A comparative analysis of this $16 \mathrm{~S}$ rDNA sequence with the sequences available for representatives of the major bacterial groups indicated that strain $\mathrm{Z}-7935^{\mathrm{T}}$ is a member of the delta subclass of the Proteobacteria. In order to complete the data set for the halophilic members of the delta subclass of the Proteobacteria, the 16S rDNA sequences of Desulfohalo- bium retbaense DSM $5692^{\mathrm{T}}$ and Desulfovibrio halophilus DSM $5663^{\mathrm{T}}$ were determined and included in the phylogenetic analysis. The phylogenetic dendrogram in Fig. 4 shows the position of strain Z-7935 ${ }^{\mathrm{T}}$ within the radiation of the members of the delta subclass of the Proteobacteria for which $16 \mathrm{~S}$ rDNA sequence data are available. Strain $\mathrm{Z}-7935^{\mathrm{T}}$ represents a distinct lineage, clustering with Desulfohalobium retbaense and strain TD3 (13). The highest levels of 16S rDNA sequence similarity were the levels of similarity between strain $\mathrm{Z}-7935^{\mathrm{T}}$ and Desulfohalobium retbaense $(88.7 \%)$ and between strains $\mathrm{Z}-7935^{\mathrm{T}}$ and TD3 (86.6\%) (Table 2).

\section{DISCUSSION}

The role of hydrogen-consuming, sulfate-reducing bacteria in the alkaliphilic community investigated in this study is interesting from an ecological and physiological viewpoint. The type of nutrition displayed by strain $\mathrm{Z}-7935^{\mathrm{T}}$ is typical of lithoheterotrophic, sulfate-reducing bacteria that utilize hydrogen or formate for the reduction of oxidized sulfur compounds in the catabolic reaction and acetate in the anabolic pathway (16). Strain Z-7935 ${ }^{\mathrm{T}}$ differs from other sulfate-reducing bacteria by its unusually narrow range of electron donors utilized. Strain $\mathrm{Z}-7935^{\mathrm{T}}$ is a lithoheterotrophic, sodium-dependent alkaliphile which may be responsible for the consumption of hydrogen in the alkaliphilic community from which it was isolated. This organism is clearly a member of an alkaliphilic anaerobic community in which primary anaerobes (e.g., alkaliphilic spirochetes $[27,28]$ ) produce hydrogen and acetate.

The geographical distribution of alkaliphilic sulfate reducers in continental soda lakes was revealed by the study of anaerobic communities in the lakes of Central Asia. Physiologically similar pure cultures were isolated from four alkaline lakes in Tuva, and these cultures were found to belong to the same species and to have DNA-DNA homology values of more than 90\% (7). It was demonstrated that in Asian lakes, which represent a range of $\mathrm{pH}$ and salinity combinations and harbor different microbial communities, as in "natural elective cul-

TABLE 2. 16S rDNA similarity values for strain $\mathrm{Z}-7935^{\mathrm{T}}$ and related taxa

\section{$\% 16 \mathrm{~S}$ rDNA similarity to:}

\begin{tabular}{|c|c|c|c|c|c|c|c|c|c|c|c|c|c|c|c|c|c|}
\hline Organism & 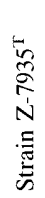 & 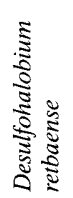 & 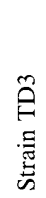 & 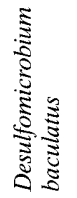 & 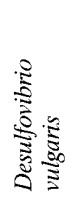 & 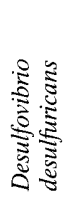 & 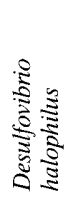 & 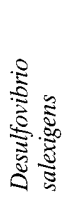 & 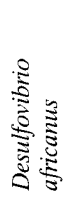 & 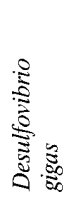 & 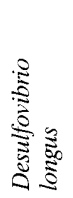 & 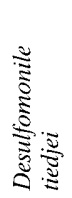 & 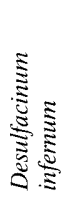 & 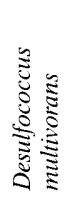 & 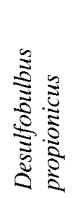 & 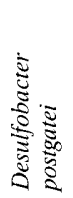 & 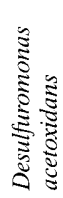 \\
\hline
\end{tabular}

\begin{tabular}{|c|c|c|c|c|c|c|c|c|c|c|c|c|c|c|c|c|c|}
\hline Desulfohalobium retbaense & 88.7 & & & & & & & & & & & & & & & & \\
\hline Strain TD3 & 86.6 & 88.0 & & & & & & & & & & & & & & & \\
\hline Desulfomicrobium baculatus & 86.5 & 85.7 & 85.1 & & & & & & & & & & & & & & \\
\hline Desulfovibrio vulgaris & 86.0 & 85.9 & 85.8 & 85.9 & & & & & & & & & & & & & \\
\hline Desulfovibrio desulfuricans & 86.3 & 85.9 & 85.0 & 87.4 & 91.9 & & & & & & & & & & & & \\
\hline Desulfovibrio halophilus & 86.5 & 86.7 & 85.8 & 86.5 & 88.3 & 87.8 & & & & & & & & & & & \\
\hline Desulfovibrio salexigens & 87.1 & 87.1 & 85.9 & 85.5 & 88.4 & 87.4 & 91.0 & & & & & & & & & & \\
\hline Desulfovibrio africanus & 86.5 & 85.6 & 84.7 & 87.1 & 90.3 & 89.0 & 88.6 & 87.8 & & & & & & & & & \\
\hline Desulfovibrio gigas & 87.1 & 88.1 & 86.5 & 85.5 & 87.8 & 89.0 & 87.6 & 87.0 & 89.1 & & & & & & & & \\
\hline Desulfovibrio longus & 86.3 & 86.6 & 84.9 & 86.1 & 89.1 & 89.2 & 90.2 & 89.2 & 89.5 & 88.7 & & & & & & & \\
\hline Desulfomonile tiedjei & 82.9 & 83.3 & 82.5 & 81.7 & 81.4 & 82.4 & 83.7 & 81.5 & 82.7 & 82.6 & 84.1 & & & & & & \\
\hline Desulfacimum infermum & 83.2 & 84.4 & 84.1 & 82.5 & 82.4 & 82.7 & 82.3 & 82.0 & 83.5 & 83.5 & 82.9 & 87.2 & & & & & \\
\hline Desulfococcus multivorans & 83.9 & 84.3 & 83.2 & 84.4 & 83.5 & 84.1 & 85.1 & 83.0 & 83.4 & 83.4 & 84.0 & 87.9 & 86.5 & & & & \\
\hline Desulfobulbus propionicus & 84.0 & 84.0 & 84.2 & 83.0 & 83.9 & 83.5 & 82.9 & 82.1 & 82.5 & 83.4 & 83.5 & 85.8 & 86.4 & 85.2 & & & \\
\hline Desulfobacter postgatei & 83.0 & 82.8 & 80.7 & 83.4 & 81.5 & 83.0 & 81.7 & 82.0 & 82.3 & 83.1 & 82.7 & 84.0 & 83.5 & 87.0 & 85.3 & & \\
\hline Desulfuromonas acetoxidans & 85.3 & 85.3 & 83.4 & 83.6 & 84.1 & 84.5 & 84.6 & 84.4 & 84.4 & 85.3 & 84.5 & 87.6 & 86.4 & 86.1 & 87.1 & 86.4 & \\
\hline Escherichia coli & 80.1 & 80.3 & 80.0 & 79.5 & 79.8 & 79.8 & 80.6 & 79.5 & 80.5 & 79.4 & 79.2 & 80.0 & 78.1 & 81.2 & 80.8 & 78.2 & 80.9 \\
\hline
\end{tabular}


TABLE 3. Comparison of the main characteristics of Desulfonatronovibrio hydrogenovorans Z-7935 ${ }^{\mathrm{T}}$ and some other sulfate-reducing bacteria

\begin{tabular}{|c|c|c|c|c|c|}
\hline Characteristic & 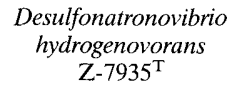 & $\begin{array}{c}\text { Desulfovibrio } \\
\text { halophilus SL } 8903^{a}\end{array}$ & $\begin{array}{l}\text { Desulfovibrio } \\
\text { salexigens }^{b}\end{array}$ & $\begin{array}{l}\text { Desulfohalobium } \\
\text { retbaense HR100' }\end{array}$ & Strain $\mathrm{TD}^{d}$ \\
\hline Cell shape & Vibrio & Vibrio & Vibrio & Curved rod & Curved rod \\
\hline Motility (monopolar) & + & + & + & & $\mathrm{NR}^{f}$ \\
\hline Cell size $(\mu \mathrm{m})$ & $0.5 \times 1.5-2.0$ & $0.6 \times 2.5-5.0$ & $0.5-1.0 \times 3.5$ & $0.7-0.9 \times 1.0-3.0$ & $0.8 \times 2.0$ \\
\hline $\mathrm{pH}$ range (optimal $\mathrm{pH}$ ) & $8.0-10.2(9.5-9.7)$ & $5.5-8.5(6.5)$ & NR $(7.0)$ & $5.5-8.0(6.5-7.0)$ & $\mathrm{NR}(6.8)$ \\
\hline $\begin{array}{l}\text { Salinity range (optimal } \\
\text { salinity) }(\%)\end{array}$ & $1.0-12.0(3.0)$ & $3.0-18.0(6.0-7.0)$ & $0.5-12.0(2.0-4.0)$ & $1.0-24.0(10.0)$ & NR (3.5) \\
\hline Optimal temp $\left({ }^{\circ} \mathrm{C}\right)$ & 37 & 35 & $34-37$ & $37-40$ & $55-65$ \\
\hline $\begin{array}{l}\text { Yeast extract } \\
\text { requirement }\end{array}$ & + & - & - & + & NR \\
\hline $\begin{array}{l}\mathrm{G}+\mathrm{C} \text { content of DNA } \\
(\mathrm{mol} \%)\end{array}$ & 48.6 & 60.7 & $46.0-49.0$ & 57.1 & NR \\
\hline \multicolumn{6}{|l|}{$\begin{array}{l}\text { Utilization of electron } \\
\text { donors (with } \mathrm{SO}_{4}{ }^{2-} \text { ) }\end{array}$} \\
\hline $\mathrm{H}_{2}+\mathrm{CO}_{2}$ & - & - & - & - & - \\
\hline $\mathrm{H}_{2}+$ acetate & + & + & + & + & - \\
\hline Formate + acetate & + & + & + & + & - \\
\hline Lactate & - & + & + & + & - \\
\hline Pyruvate & - & + & + & + & NR \\
\hline Malate & - & - & + & - & NR \\
\hline Fumarate & - & - & - & - & NR \\
\hline Acetate & - & - & - & - & NR \\
\hline Propionate & - & - & - & - & NR \\
\hline Ethanol & - & + & + & + & - \\
\hline Glycerol & - & - & - & - & NR \\
\hline Serine & - & + & NR & NR & NR \\
\hline Fatty acids $\left(\mathrm{C}_{14}-\mathrm{C}_{18}\right)$ & $\mathrm{ND}^{g}$ & NR & NR & NR & + \\
\hline$n$-Alkanes $\left(\mathrm{C}_{6}-\mathrm{C}_{16}\right)$ & ND & NR & NR & NR & + \\
\hline $\begin{array}{l}\text { Fermentation of pyruvate } \\
\left(\text { no } \mathrm{SO}_{4}{ }^{2-}\right)\end{array}$ & - & - & - & $+/-^{h}$ & NR \\
\hline \multicolumn{6}{|l|}{$\begin{array}{l}\text { Utilization of electron } \\
\text { acceptors }\end{array}$} \\
\hline Sulfate & + & + & + & + & + \\
\hline Sulfite & + & + & NR & + & NR \\
\hline Thiosulfate & + & + & NR & + & NR \\
\hline Sulfur & - & + & NR & + & NR \\
\hline
\end{tabular}

${ }^{a}$ Data from reference 3 .

${ }^{b}$ Data from references 11 and 23 .

${ }^{c}$ Data from reference 8.

${ }^{d}$ Data from reference 13

One or two flagella are present.

$f$ NR, not reported.

${ }^{g} \mathrm{ND}$, not determined.

$h+/-$, substrates are used as donors, but growth is slow.

tures," hydrogen-consuming sulfate-reducing bacteria are dominant at levels of salinity up to $15 \%$ (26). Organisms such as strain $\mathrm{Z}-7935^{\mathrm{T}}$ represent the putative alkaliphilic sulfate reducers that may be responsible for the formation of alkaline conditions up to $\mathrm{pH} 10$. The complete breakdown of organic matter by anaerobes requires the removal of hydrogen; this is achieved by conversion of the hydrogen to $\mathrm{H}_{2} \mathrm{~S}$. The $\mathrm{H}_{2} \mathrm{~S}$ in turn is oxidized anaerobically by purple bacteria (e.g., in the alkaliphilic community in Lake Magadi by Ectothiorhodospira species) or aerobically by alkaliphilic thionic bacteria, as in Asian Lake Khadyn (15). In accordance with the assumption that athalassic soda lakes may harbor novel terrestrial communities (25), the new alkaliphilic isolate represents a distinct phylogenetic lineage whose closest relative is the moderately halophilic organism Desulfohalobium retbaense. A comparison of the characteristics of strain $\mathrm{Z}-7935^{\mathrm{T}}$ with those of halophilic, sulfate-reducing bacteria is shown in Table 3. Strain Z-7935 clearly represents a new taxon of sulfate-reducing bacteria, since it has a unique combination of characteristics and grows in a habitat from which pure cultures of sulfate-reducing bac- teria have not been isolated. Morphologically, strain Z-7935 ${ }^{\mathrm{T}}$ resembles typical desulfovibrios. This typical morphology is found in species of the genera Desulfovibrio, Desulfobacter, and Desulfobacterium (23). Desulfoviridin is not present in strain $\mathrm{Z}-7935^{\mathrm{T}}$, and the $\mathrm{G}+\mathrm{C}$ content of this organism is $48.6 \mathrm{~mol} \%$, which is similar to the values reported for Desulfovibrio salexigens and Desulfovibrio simplex, which are phenotypically and phylogenetically distinct from strain Z-7935 ${ }^{\mathrm{T}}$. The halophilic species Desulfobacter hydrogenophilus can utilize $\mathrm{H}_{2}$ in addition to acetate (22). The halophilic organism Desulfohalobium retbaense (8) could be considered a thalassic counterpart of alkaliphilic strain $Z-7935^{\mathrm{T}}$. The fatty acid profile of strain $\mathrm{Z}-7935^{\mathrm{T}}$ contains compounds that are typical of the membranes of members of the bacterial domain and are associated with sulfate-reducing bacterial species $(8,19)$. The lipid profile of sulfate-reducing bacteria is quite characteristic, and the profiles of strain Z-7935 ${ }^{\mathrm{T}}$ and 72 sulfate-reducing bacteria, including previously studied Desulfovibrio species (19), were compared. The lipid profile of strain $\mathrm{Z}-7935^{\mathrm{T}}$ lacks iso- $\mathrm{C}_{17.1}$ fatty acids, which are biomarkers of species of the genus Desulfo- 
vibrio. On the basis of its fatty acid profile, strain $\mathrm{Z}-7935^{\mathrm{T}}$ cannot be affiliated with any species except Desulfohalobium retbaense and Desulfomicrobium baculatus [sic] (correlation coefficient, 0.23). On the basis of the phylogenetic analysis it can be concluded that strain $\mathrm{Z}-7935^{\mathrm{T}}$ is a member of a recently discovered new lineage within the delta branch of the Proteobacteria that comprises hydrocarbon-utilizing strain TD3 (13) and Desulfohalobium retbaense (Fig. 4 and Table 2). With its distinct branch point and 16S rDNA sequence difference of $>11 \%$ compared with its nearest relative, as well as its distinct phenotypic characteristics (Table 3 ), strain Z-7935 ${ }^{\mathrm{T}}$ clearly represents a new genus. We propose that the alkaliphilic, sulfate-reducing strain $\mathrm{Z}-7935^{\mathrm{T}}$ should be placed in a new genus and species, Desulfonatronovibrio hydrogenovorans; the name of this organism describes its ecophysiology.

Description of Desulfonatronovibrio gen. nov. Desulfonatronovibrio (De.sul.fo.nat.ro.no.vi' b.rio. M. L. pref. de, negative; M.L.n. sulfo, sulfate; M.L.n. natron, soda; M.L.n. vibrio, curved rod; M.L.n. Desulfonatronovibrio, sulfate-reducing curved rod from a soda environment). Alkaliphilic sulfatereducing eubacterium. Cells are motile, asporogenous, gramnegative vibrios with polar flagella. Lithoheterotrophic, utilizing hydrogen for the reduction of sulfur compounds. Strictly anaerobic. Obligately dependent on sodium ions. Vitamins and acetate as a carbon source are necessary for growth on hydrogen or formate and can be replaced by yeast extract. Phylogenetically a member of the delta subclass of the Proteobacteria. The type species is Desulfonatronovibrio hydrogenovorans.

Description of Desulfonatronovibrio hydrogenovorans sp. nov. Desulfonatronovibrio hydrogenovorans (hy.dro.ge.no.vo'rans. M.L.n. hydrogen, hydrogen; M.L. part. vorans, utilizing; M.L. part. hydrogenovorans, hydrogen utilizing). Motile vibrio with one polar flagellum. Cells are 0.5 by 1.5 to $2 \mu \mathrm{m}$, occur singly or in pairs, and develop short spirilla under suboptimal conditions. Multiplication is by binary fission. Gram-negative cell wall structure. Strictly anaerobic and lithoheterotrophic. Utilizes only hydrogen and formate as electron donors and sulfate, sulfite, and thiosulfate as electron acceptors. Sulfur is not reduced. Sulfide is the only product of catabolism. Yeast extract and acetate are utilized for anabolism. Obligate alkaliphile which does not grow at $\mathrm{pH} 7$; the maximum $\mathrm{pH}$ for growth is about 10.2, and the optimal $\mathrm{pH}$ for growth and sulfidogenesis in sodium carbonate medium is 9.5 to 9.7 . Sodium ions are required for growth; no growth occurs in the presence of $\mathrm{NaCl}$ concentrations less than $1 \%(\mathrm{wt} / \mathrm{vol})$ or more than $12 \%(\mathrm{wt} /$ vol). Growth occurs if $\mathrm{NaCl}$ is replaced by equimolar amounts of $\mathrm{Na}_{2} \mathrm{CO}_{3}$ and $\mathrm{NaHCO}_{3}$. Requires carbonate anion. The optimum temperature for growth is $37^{\circ} \mathrm{C}$, and the temperature range for growth is 15 to $43^{\circ} \mathrm{C}$. Slow growth occurs at 22 to $26^{\circ} \mathrm{C}$ after a long lag phase. The $\mathrm{G}+\mathrm{C}$ content of the DNA is $48.6 \mathrm{~mol} \%$ (as determined by the thermal denaturation method). Habitat: bottom deposits of alkaline athalassic soda lakes. The type strain is strain Z-7935, which was isolated from the sediments of an equatorial soda lake, Lake Magadi. This strain has been deposited in the Deutsche Sammlung von Mikroorganismen as strain DSM $9292^{\mathrm{T}}$.

\section{ACKNOWLEDGMENTS}

We are grateful to A. M. Lysenko for determining the DNA G + C content and to Marcus Schmidt for assistance in preparing graphics. We thank B. Tindall for providing rare old literature on Lake Magadi.

This work was supported in part by grants to G.A.Z. from ISF 68300 and from the Russian State "Biodiversity" program.

\section{REFERENCES}

1. Abd-el-Malek, Y., and S. G. Rizk. 1963. Bacterial sulphate reduction and the development of alkalinity. III. Experiments under natural conditions. J. Appl. Bacteriol. 26:20-26.

2. Baker, B. H. 1958 . The geology of the Magadi area. Report no. 42 , p. 81 . Geological Survey of Kenya, Nairobi, Kenya.

3. Caumette, P., Y. Cohen, and R. Matheron. 1991. Isolation and characterization of Desulfovibrio halophilus sp. nov., a halophilic sulfate-reducing bacterium isolated from Solar Lake (Sinai). Syst. Appl. Microbiol. 14:33-38.

4. Cypionka, H., and N. Pfennig. 1986. Growth yields of Desulfotomaculum orientis with hydrogen in chemostat culture. Arch. Microbiol. 143:396-399.

5. Ivanov, M. V. 1956. Application of isotopes for the studying sulfate reduction in Lake Belovod. Mikrobiologiya 25:305-309.

6. Jukes, T. H., and C. R. Cantor. 1969. Evolution of protein molecules, p. 21-132. In H. N. Munro (ed.), Mammalian protein metabolism. Academic Press, New York, N.Y.

7. Lysenko, A., and E. Pikuta. Unpublished data.

8. Ollivier, B., C. E. Hatchikian, G. Prensier, J. Guezennec, and J. L. Garcia. 1991. Desulfohalobium retbaense gen. nov., sp. nov., a halophilic sulfatereducing bacterium from sediments of a hypersaline lake in Senegal. Int. J. Syst. Bacteriol. 41:74-81.

9. Owen, R. J., R. Hill, and S. P. Lapage. 1969. Determination of DNA base composition from melting profiles in dilute buffers. Biopolymers 7:503-516.

10. Postgate, J. R. 1984. The sulphate-reducing bacteria, 2nd ed. Cambridge University Press, Cambridge, United Kingdom

11. Postgate, J. R., and L. L. Campbell. 1966. Classification of Desulfovibrio species, the nonsporulating sulfate-reducing bacteria. Bacteriol. Rev. 30: 732-738.

12. Rainey, F. A., N. Ward-Rainey, R. M. Kroppenstedt, and E. Stackebrandt. 1996. The genus Nocardiopsis represents a phylogenetically coherent taxon and a distinct actinomycete lineage: proposal of Nocardiopsaceae fam. nov. Int. J. Syst. Bacteriol. 46:1088-1092.

13. Rueter, P., R. Rabus, H. Wilkes, F. Aeckersberg, F. A. Rainey, H. W. Jannasch, and F. Widdel. 1994. Anaerobic oxidation of hydrocarbons in crude oil by new types of sulphate-reducing bacteria. Nature 372:455-458.

14. Saitou, N., and M. Nei. 1987 . The neighbor-joining method: a new method for reconstructing phylogenetic trees. Mol. Biol. Evol. 4:406-425.

15. Sorokin, D. Y., A. M. Lysenko, and L. L. Mitushina. 1996. Isolation and characterization of alkaliphilic heterotrophic bacteria, which oxidize reduced sulfur compounds to tetrationate. Microbiology 65:326-338.

16. Sorokin, Y. 1966. Role of carbon dioxide and acetate in biosynthesis by sulfate-reducing bacteria. Nature 210:551-552.

17. Tindall, B. J. 1986. Procaryotic life in the alkaline, saline, athalassic environment, p. 31-67. In F. Rodriguez-Valera (ed.), Halophilic bacteria. CRC Press, Boca Raton, Fla.

18. Trüper, H. G., and H. G. Schlegel. 1964. Sulphur methabolism in Thiorhodacaae. I. Quantitative measurements on growing cells of Chromatium okenii. Antonie van Leeuwenhoek. J. Microbiol. Serol. 30:225-238.

19. Vainshtein, M., H. Hippe, and R. M. Kroppenstedt. 1992. Cellular fatty acid composition of Desulfovibrio species and its use in classification of sulfatereducing bacteria. Syst. Appl. Microbiol. 15:554-566.

20. Vainshtein, M. B., and C. S. Laurinavichus. 1988. Enumeration and cultivation of anaerobic bacteria. Institute of Biochemistry and Physiology of Microorganisms, Russian Academy of Sciences, Pushchino, Russia.

21. Whitman, W. B., E. Ankwanda, and M. L. Wolfe. 1982. Nutrition and carbon metabolism of Methanococcus voltae. J. Bacteriol. 149:852-863.

22. Widdel, F. 1987. New types of acetate-oxidizing, sulfate-reducing Desulfobacter species, D. hydrogenophilus sp. nov., D. latus sp. nov., and D. curvatus sp. nov. Arch. Microbiol. 148:286-291.

23. Widdel, F. 1988. Microbiology and ecology of sulfate- and sulfur-reducing bacteria, p. 469-585. In A. J. B. Zehnder (ed.), Biology of anaerobic microorganisms. John Wiley \& Sons, New York, N.Y.

24. Wolin, E. A., M. J. Wolin, and R. S. Wolfe. 1963. Formation of methane by bacterial extracts. J. Biol. Chem. 238:2882-2886.

25. Zavarzin, G. A. 1993. Epicontinental alkaline water bodies as relict biotopes for the development of terrestrial biota. Microbiology 62:789-800.

26. Zavarzin, G. A., T. N. Zhilina, and E. V. Pikuta. 1996. Secondary anaerobes in the haloalkaliphilic communities in Tuva Lakes. Microbiologia 65:480486.

27. Zhilina, T. N., and G. A. Zavarzin. 1994. Alkaliphilic anaerobic community at pH 10. Curr. Microbiol. 29:109-112.

28. Zhilina, T. N., G. A. Zavarzin, F. Rainey, V. V. Kevbrin, N. A. Kostrikina, and A. M. Lysenko. 1996. Spirochaeta alkalica sp. nov., Spirochaeta africana sp. nov., and Spirochaeta asiatica sp. nov., alkaliphilic anaerobes from the continental soda lakes in Central Asia and the East African Rift. Int. J. Syst. Bacteriol. 46:305-312. 